Marquette University

e-Publications@Marquette

History Faculty Research and Publications

History, Department of

$1-1-2011$

\title{
Fascist Ecology: The "Green Wing" of the Nazi Party and its Historical Antecedents
}

Peter Staudenmaier

Marquette University, peter.staudenmaier@marquette.edu

Published version. "Fascist Ecology: The "Green Wing" of the Nazi Party and its Historical Antecedents," in Ecofascism Revisited: Lessons from the German Experience. Eds. Janet Biehl and Peter Staudenmaier. Porsgrunn: New Compass Press, 2011: 13-42. Permalink. (C) 2011 New Compass Press. 
PETER STAUDENMAIER

\title{
FASCIST ECOLOGY: THE "GREEN WING" OF THE NAZI PARTY AND ITS HISTORICAL ANTECEDENTS
}

\begin{abstract}
"We recognize that separating humanity from nature, from the whole of life, leads to humankind's own destruction and to the death of nations. Only through a re-integration of humanity into the whole of nature can our people be made stronger. That is the fundamental point of the biological tasks of our age. Humankind alone is no longer the focus of thought, but rather life as a whole ... This striving toward connectedness with the totality of life, with nature itself, a nature into which we are born, this is the deepest meaning and the true essence of National Socialist thought."1
\end{abstract}

In our zeal to condemn the status quo, radicals often carelessly toss about epithets like "fascist" and "ecofascist," thus contributing to a sort of conceptual inflation that in no way furthers effective social critique. In such a situation, 
it is easy to overlook the fact that there are still virulent strains of fascism in our political culture which, however marginal, demand our attention. One of the least recognized or understood of these strains is the phenomenon one might call "actually existing ecofascism," that is, the preoccupation of authentically fascist movements with environmentalist concerns. In order to grasp the peculiar intensity and endurance of this affiliation, we would do well to examine more closely its most notorious historical incarnation, the socalled "green wing" of German National Socialism.

Despite an extensive documentary record, the subject remains an elusive one, underappreciated by professional historians and environmental activists alike. In Englishspeaking countries as well as in Germany itself, the very existence of a "green wing" in the Nazi movement, much less its inspiration, goals, and consequences, has yet to be adequately researched and analyzed. Most of the handful of available interpretations succumb to either an alarming intellectual affinity with their subject ${ }^{2}$ or a naive refusal to examine the full extent of the "ideological overlap between nature conservation and National Socialism." ${ }^{3}$ This article presents a brief and necessarily schematic overview of the ecological components of Nazism, emphasizing both their central role in Nazi ideology and their practical implementation during the Third Reich. A preliminary survey of nineteenth and twentieth century precursors to classical ecofascism should serve to illuminate the conceptual underpinnings common to all forms of reactionary ecology.

Two initial clarifications are in order. First, the terms "environmental" and "ecological" are here used more 
or less interchangeably to denote ideas, attitudes, and practices commonly associated with the contemporary environmental movement. This is not an anachronism; it simply indicates an interpretive approach which highlights connections to present-day concerns. Second, this approach is not meant to endorse the historiographically discredited notion that pre-1933 historical data can or should be read as "leading inexorably" to the Nazi calamity. Rather, our concern here is with discerning ideological continuities and tracing political genealogies, in an attempt to understand the past in light of our current situation-to make history relevant to the present social and ecological crisis.

\section{The Roots of the Blood and Soil Mystique}

Germany is not only the birthplace of the science of ecology and the site of Green politics' rise to prominence; it has also been home to a peculiar synthesis of naturalism and nationalism forged under the influence of the Romantic tradition's anti-Enlightenment irrationalism. Two nineteenth century figures exemplify this ominous conjunction: Ernst Moritz Arndt and Wilhelm Heinrich Riehl.

While best known in Germany for his fanatical nationalism, Arndt was also dedicated to the cause of the peasantry, which led him to a concern for the welfare of the land itself. Historians of German environmentalism mention him as the earliest example of 'ecological' thinking in the modern sense. ${ }^{4}$ His remarkable 1815 article On the Care and Conservation of Forests, written 
at the dawn of industrialization in Central Europe, rails against shortsighted exploitation of woodlands and soil, condemning deforestation and its economic causes. At times he wrote in terms strikingly similar to those of contemporary biocentrism: "When one sees nature in a necessary connectedness and interrelationship, then all things are equally important-shrub, worm, plant, human, stone, nothing first or last, but all one single unity."

Arndt's environmentalism, however, was inextricably bound up with virulently xenophobic nationalism. His eloquent and prescient appeals for ecological sensitivity were couched always in terms of the well-being of the German soil and the German people, and his repeated lunatic polemics against miscegenation, demands for Teutonic racial purity, and epithets against the French, Slavs, and Jews marked every aspect of his thought. At the very outset of the nineteenth century the deadly connection between love of land and militant racist nationalism was firmly set in place.

Riehl, a student of Arndt, further developed this sinister tradition. In some respects his 'green' streak went significantly deeper than Arndt's; presaging certain tendencies in recent environmental activism, his 1853 essay Field and Forest ended with a call to fight for "the rights of wilderness." But even here nationalist pathos set the tone: "We must save the forest, not only so that our ovens do not become cold in winter, but also so that the pulse of life of the people continues to beat warm and joyfully, so

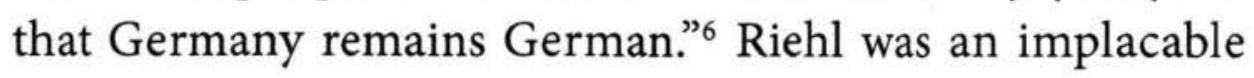
opponent of the rise of industrialism and urbanization; his overtly antisemitic glorification of rural peasant values and 
undifferentiated condemnation of modernity established him as the "founder of agrarian romanticism and antiurbanism."

These latter two fixations matured in the second half of the nineteenth century in the context of the völkisch movement, a powerful cultural disposition and social tendency which united ethnocentric populism with nature mysticism. At the heart of the völkisch temptation was a pathological response to modernity. In the face of the very real dislocations brought on by the triumph of industrial capitalism and national unification, völkisch thinkers preached a return to the land, to the simplicity and wholeness of a life attuned to nature's purity. The mystical effusiveness of this perverted utopianism was matched by its political vulgarity. While "the Volkish movement aspired to reconstruct the society that was sanctioned by history, rooted in nature, and in communion with the cosmic life spirit," ${ }^{\prime 8}$ it pointedly refused to locate the sources of alienation, rootlessness and environmental destruction in social structures, laying the blame instead to rationalism, cosmopolitanism, and urban civilization. The stand-in for all of these was the ageold object of peasant hatred and middle-class resentment: the Jews. "The Germans were in search of a mysterious wholeness that would restore them to primeval happiness, destroying the hostile milieu of urban industrial civilization that the Jewish conspiracy had foisted on them."'.

Reformulating traditional German antisemitism into nature-friendly terms, the völkisch movement carried a volatile amalgam of nineteenth century cultural prejudices, Romantic obsessions with purity, and anti-Enlightenment sentiment into twentieth century political discourse. The 
emergence of modern ecology forged the final link in the fateful chain which bound together aggressive nationalism, mystically charged racism, and environmentalist predilections. In 1867 the German zoologist Ernst Haeckel coined the term 'ecology' and began to establish it as a scientific discipline dedicated to studying the interactions between organism and environment. Haeckel was also the chief popularizer of Darwin and evolutionary theory for the German-speaking world, and developed a peculiar sort of social darwinist philosophy he called 'monism.' The German Monist League he founded combined scientifically based ecological holism with völkisch social views. Haeckel believed in Nordic racial superiority, strenuously opposed race mixing and enthusiastically supported racial eugenics. His fervent nationalism became fanatical with the onset of World War I, and he fulminated in antisemitic tones against the post-war Council Republic in Bavaria.

In this way "Haeckel contributed to that special variety of German thought which served as the seed bed for National Socialism. He became one of Germany's major ideologists for racism, nationalism and imperialism." ${ }^{10}$ Near the end of his life he joined the Thule Society, "a secret, radically right-wing organization which played a key role in the establishment of the Nazi movement."11 But more than merely personal continuities are at stake here. The pioneer of scientific ecology, along with his disciples Willibald Hentschel, Wilhelm Bölsche and Bruno Wille, profoundly shaped the thinking of subsequent generations of environmentalists by embedding concern for the natural world in a tightly woven web of regressive social themes. From its very beginnings, 
then, ecology was bound up in an intensely reactionary political framework.

The specific contours of this early marriage of ecology and authoritarian social views are highly instructive. At the center of this ideological complex is the direct, unmediated application of biological categories to the social realm. Haeckel held that "civilization and the life of nations are governed by the same laws as prevail throughout nature and organic life."12 This notion of 'natural laws' or 'natural order' has long been a mainstay of reactionary environmental thought. Its concomitant is anti-humanism:

Thus, for the Monists, perhaps the most pernicious feature of European bourgeois civilization was the inflated importance which it attached to the idea of man in general, to his existence and to his talents, and to the belief that through his unique rational faculties man could essentially recreate the world and bring about a universally more harmonious and ethically just social order. [Humankind was] an insignificant creature when viewed as part of and measured against the vastness of the cosmos and the overwhelming forces of nature. ${ }^{13}$

Other Monists extended this anti-humanist emphasis and mixed it with the traditional völkisch motifs of indiscriminate anti-industrialism and anti-urbanism as well as the newly emerging pseudo-scientific racism. The linchpin, once again, was the conflation of biological and social categories. The biologist Raoul Francé, founding member of the Monist League, elaborated so-called Lebensgesetze, 'laws of life' through which the natural order determines the social order. 
He opposed racial mixing, for example, as "unnatural." Francé is acclaimed by contemporary ecofascists as a "pioneer of the ecology movement." ${ }^{14}$

Francés colleague Ludwig Woltmann, another student of Haeckel, insisted on a biological interpretation for all societal phenomena, from cultural attitudes to economic arrangements. He stressed the supposed connection between environmental purity and 'racial' purity: "Woltmann took a negative attitude toward modern industrialism. He claimed that the change from an agrarian to an industrial society had hastened the decline of the race. In contrast to nature, which engendered the harmonic forms of Germanism, there were the big cities, diabolical and inorganic, destroying the virtues of the race."15

Thus by the early years of the twentieth century a certain type of 'ecological' argumentation, saturated with right-wing political content, had attained a measure of respectability within the political culture of Germany. During the turbulent period surrounding World War I, the mixture of ethnocentric fanaticism, regressive rejection of modernity and genuine environmental concern proved to be a very potent potion indeed.

\section{The Youth Movement and the Weimar Era}

The chief vehicle for carrying this ideological constellation to prominence was the youth movement, an amorphous phenomenon which played a decisive but highly ambivalent role in shaping German popular culture during the first three tumultuous decades of this century. Also known as the Wandervögel (which translates roughly as 'wandering 
free spirits'), the youth movement was a hodge-podge of countercultural elements, blending neo-Romanticism, Eastern philosophies, nature mysticism, hostility to reason, and a strong communal impulse in a confused but no less ardent search for authentic, non-alienated social relations. Their back-to-the-land emphasis spurred a passionate sensitivity to the natural world and the damage it suffered. They have been aptly characterized as 'right-wing hippies,' for although some sectors of the movement gravitated toward various forms of emancipatory politics (though usually shedding their environmentalist trappings in the process), most of the Wandervögel were eventually absorbed by the Nazis. This shift from nature worship to Führer worship is worth examining.

The various strands of the youth movement shared a common self-conception: they were a purportedly 'nonpolitical' response to a deep cultural crisis, stressing the primacy of direct emotional experience over social critique and action. They pushed the contradictions of their time to the breaking point, but were unable or unwilling to take the final step toward organized, focused social rebellion, "convinced that the changes they wanted to effect in society could not be brought about by political means, but only by the improvement of the individual."16 This proved to be a fatal error. "Broadly speaking, two ways of revolt were open to them: they could have pursued their radical critique of society, which in due course would have brought them into the camp of social revolution. [But] the Wandervögel chose the other form of protest against society-romanticism. ${ }^{17}$

This posture lent itself all too readily to a very different kind of political mobilization: the 'unpolitical' zealotry of 
fascism. The youth movement did not simply fail in its chosen form of protest, it was actively realigned when its members went over to the Nazis by the thousands. Its countercultural energies and its dreams of harmony with nature bore the bitterest fruit. This is, perhaps, the unavoidable trajectory of any movement which acknowledges and opposes social and ecological problems but does not recognize their systemic roots or actively resist the political and economic structures which generate them. Eschewing societal transformation in favor of personal change, an ostensibly apolitical disaffection can, in times of crisis, yield barbaric results.

The attraction such perspectives exercised on idealistic youth is clear: the enormity of the crisis seemed to enjoin a total rejection of its apparent causes. It is in the specific form of this rejection that the danger lies. Here the work of several more theoretical minds from the period is instructive. The philosopher Ludwig Klages profoundly influenced the youth movement and particularly shaped their ecological consciousness. He authored a tremendously important essay titled "Man and Earth" for the legendary Meissner gathering of the Wandervögel in $1913 .{ }^{18}$ An extraordinarily poignant text and the best known of all Klages' work, it is not only "one of the very greatest manifestoes of the radical ecopacifist movement in Germany,"19 but also a classic example of the seductive terminology of reactionary ecology.

"Man and Earth" anticipated just about all of the themes of the contemporary ecology movement. It decried the accelerating extinction of species, disturbance of global ecosystemic balance, deforestation, destruction of aboriginal peoples and of wild habitats, urban sprawl, and the increasing alienation of people 
from nature. In emphatic terms it disparaged Christianity, capitalism, economic utilitarianism, hyperconsumption and the ideology of 'progress.' It even condemned the environmental destructiveness of rampant tourism and the slaughter of whales, and displayed a clear recognition of the planet as an ecological totality. All of this in 1913!

It may come as a surprise, then, to learn that Klages was throughout his life politically archconservative and a venomous antisemite. One historian labels him a "Volkish fanatic" and another considers him simply "an intellectual pacemaker for the Third Reich" who "paved the way for fascist philosophy in many important respects." ${ }^{20}$ In "Man and Earth" a genuine outrage at the devastation of the natural environment is coupled with a political subtext of cultural despair. ${ }^{21}$ Klages' diagnosis of the ills of modern society, for all its declamations about capitalism, returns always to a single culprit: "Geist." His idiosyncratic use of this term, which means mind or intellect, was meant to denounce not only hyperrationalism or instrumental reason, but rational thought itself. Such a wholesale indictment of reason cannot help but have savage political implications. It forecloses any chance of rationally reconstructing society's relationship with nature and justifies the most brutal authoritarianism. But the lessons of Klages' life and work have been hard for ecologists to learn. In 1980, "Man and Earth" was republished as an esteemed and seminal treatise to accompany the birth of the German Greens.

Another philosopher and stern critic of Enlightenment who helped bridge fascism and environmentalism was Martin Heidegger. A much more renowned thinker than Klages, Heidegger preached "authentic Being" and harshly 
criticized modern technology, and is therefore often celebrated as a precursor of ecological thinking. On the basis of his critique of technology and rejection of humanism, contemporary deep ecologists have elevated Heidegger to their pantheon of eco-heroes:

\begin{abstract}
Heidegger's critique of anthropocentric humanism, his call for humanity to learn to "let things be," his notion that humanity is involved in a "play" or "dance" with earth, sky, and gods, his meditation on the possibility of an authentic mode of "dwelling" on the earth, his complaint that industrial technology is laying waste to the earth, his emphasis on the importance of local place and "homeland," his claim that humanity should guard and preserve things, instead of dominating them-all these aspects of Heidegger's thought help to support the claim that he is a major deep ecological theorist. ${ }^{22}$
\end{abstract}

Such effusions are, at best, dangerously naive. They suggest a style of thought utterly oblivious to the history of fascist appropriations of all the elements the quoted passage praises in Heidegger. (To his credit, the author of the above lines, a major deep ecological theorist in his own right, has since changed his position and eloquently urged his colleagues to do the same. ${ }^{23}$ As for the philosopher of Being himself, he wasunlike Klages, who lived in Switzerland after 1915-an active member of the Nazi party and for a time enthusiastically, even adoringly supported the Führer. His mystical panegyrics to Heimat (homeland) were complemented by a deep antisemitism, and his metaphysically phrased broadsides against technology and modernity converged neatly with 
populist demagogy. Although he lived and taught for thirty years after the fall of the Third Reich, Heidegger never once publicly regretted, much less renounced, his involvement with National Socialism, nor even perfunctorily condemned its crimes. His work, whatever its philosophical merits, stands today as a signal admonition about the political uses of antihumanism in ecological garb.

In addition to the youth movement and proto-fascist philosophies, there were, of course, practical efforts at protecting natural habitats during the Weimar period. Many of these projects were profoundly implicated in the ideology which culminated in the victory of 'Blood and Soil'. A 1923 recruitment pitch for a woodlands preservation outfit gives a sense of the environmental rhetoric of the time:

In every German breast the German forest quivers with its caverns and ravines, crags and boulders, waters and winds, legends and fairy tales, with its songs and its melodies, and awakens a powerful yearning and a longing for home; in all German souls the German forest lives and weaves with its depth and breadth, its stillness and strength, its might and dignity, its riches and its beauty-it is the source of German inwardness, of the German soul, of German freedom. Therefore protect and care for the German forest for the sake of the elders and the youth, and join the new German "League for the Protection and Consecration of the German Forest."24

The mantra-like repetition of the word "German" and the mystical depiction of the sacred forest fuse together, once again, nationalism and naturalism. This intertwinement 
took on a grisly significance with the collapse of the Weimar republic. For alongside such relatively innocuous conservation groups, another organization was growing which offered these ideas a hospitable home: the National Socialist German Workers Party, known by its acronym NSDAP. Drawing on the heritage of Arndt, Riehl, Haeckel, and others (all of whom were honored between 1933 and 1945 as forebears of triumphant National Socialism), the Nazi movement's incorporation of environmentalist themes was a crucial factor in its rise to popularity and state power.

\section{Nature in National Socialist Ideology}

The reactionary ecological ideas whose outlines are sketched above exerted a powerful and lasting influence on many of the central figures in the NSDAP. Weimar culture, after all, was fairly awash in such theories, but the Nazis gave them a peculiar inflection. The National Socialist "religion of nature," as one historian has described it, was a volatile admixture of primeval Teutonic nature mysticism, pseudoscientific ecology, irrationalist anti-humanism, and a mythology of racial salvation through a return to the land. Its predominant themes were 'natural order,' organicist holism and denigration of humanity: "Throughout the writings, not only of Hitler, but of most Nazi ideologues, one can discern a fundamental deprecation of humans vis-à-vis nature, and, as a logical corollary to this, an attack upon human efforts to master nature." ${ }^{25}$ Quoting a Nazi educator, the same source continues: "anthropocentric views in general had to be rejected. They would be valid only 'if it is assumed that 
nature has been created only for man. We decisively reject this attitude. According to our conception of nature, man is a link in the living chain of nature just as any other organism." 26

Such arguments have a chilling currency within contemporary ecological discourse: the key to social-ecological harmony is ascertaining "the eternal laws of nature's processes" (Hitler) and organizing society to correspond to them. The Führer was particularly fond of stressing the "helplessness of humankind in the face of nature's everlasting law."27 Echoing Haeckel and the Monists, Mein Kampf announces: "When people attempt to rebel against the iron logic of nature, they come into conflict with the very same principles to which they owe their existence as human beings. Their actions against nature must lead to their own downfall." 28

The authoritarian implications of this view of humanity and nature become even clearer in the context of the Nazis' emphasis on holism and organicism. In 1934 the director of the Reich Agency for Nature Protection, Walter Schoenichen, established the following objectives for biology curricula: "Very early, the youth must develop an understanding of the civic importance of the 'organism, i.e. the co-ordination of all parts and organs for the benefit of the one and superior task of life." ${ }^{29}$ This (by now familiar) unmediated adaptation of biological concepts to social phenomena served to justify not only the totalitarian social order of the Third Reich but also the expansionist politics of Lebensraum (the plan of conquering 'living space' in Eastern Europe for the German people). It also provided the link between environmental purity and racial purity: 


\section{ECOFASCISM REVISITED}

Two central themes of biology education follow [according to the Nazis] from the holistic perspective: nature protection and eugenics. If one views nature as a unified whole, students will automatically develop a sense for ecology and environmental conservation. At the same time, the nature protection concept will direct attention to the urbanized and 'overcivilized' modern human race. ${ }^{30}$

In many varieties of the National Socialist world view ecological themes were linked with traditional agrarian romanticism and hostility to urban civilization, all revolving around the idea of rootedness in nature. This conceptual constellation, especially the search for a lost connection to nature, was most pronounced among the neo-pagan elements in the Nazi leadership, above all Heinrich Himmler, Alfred Rosenberg, and Walther Darré. Rosenberg wrote in his colossal The Myth of the 20th Century: "Today we see the steady stream from the countryside to the city, deadly for the Volk. The cities swell ever larger, unnerving the Volk and destroying the threads which bind humanity to nature; they attract adventurers and profiteers of all colors, thereby fostering racial chaos." 31

Such musings, it must be stressed, were not mere rhetoric; they reflected firmly held beliefs and, indeed, practices at the very top of the Nazi hierarchy which are today conventionally associated with ecological attitudes. Hitler and Himmler were both strict vegetarians and animal lovers, attracted to nature mysticism and homeopathic cures, and staunchly opposed to vivisection and cruelty to animals. Himmler even established experimental organic farms to grow herbs for SS medicinal 
purposes. And Hitler, at times, could sound like a veritable Green utopian, discussing authoritatively and in detail various renewable energy sources (including environmentally appropriate hydropower and producing natural gas from sludge) as alternatives to coal, and declaring "water, winds and tides" the energy path of the future. ${ }^{32}$

Even in the midst of war, Nazi leaders maintained their commitment to ecological ideals which were, for them, an essential element of racial rejuvenation. In December 1942, Himmler released a decree "On the Treatment of the Land in the Eastern Territories," referring to the newly annexed portions of Poland. It read in part:

The peasant of our racial stock has always carefully endeavored to increase the natural powers of the soil, plants, and animals, and to preserve the balance of the whole of nature. For him, respect for divine creation is the measure of all culture. If, therefore, the new Lebensräume (living spaces) are to become a homeland for our settlers, the planned arrangement of the landscape to keep it close to nature is a decisive prerequisite. It is one of the bases for fortifying the German Volk. ${ }^{33}$

This passage recapitulates almost all of the tropes comprised by classical ecofascist ideology: Lebensraum, Heimat, the agrarian mystique, the health of the Volk, closeness to and respect for nature (explicitly constructed as the standard against which society is to be judged), maintaining nature's precarious balance, and the earthy powers of the soil and its creatures. Such motifs were anything but personal idiosyncrasies on the part of Hitler, Himmler, or Rosenberg; 
even Göring-who was, along with Goebbels, the member of the Nazi inner circle least hospitable to ecological ideasappeared at times to be a committed conservationist. ${ }^{34}$ These sympathies were also hardly restricted to the upper echelons of the party. A study of the membership rolls of several mainstream Weimar era Naturschutz (nature protection) organizations revealed that by 1939 , fully 60 percent of these conservationists had joined the NSDAP (compared to about 10 percent of adult men and 25 percent of teachers and lawyers).$^{35}$ Clearly the affinities between environmentalism and National Socialism ran deep.

At the level of ideology, then, ecological themes played a vital role in German fascism. It would be a grave mistake, however, to treat these elements as mere propaganda, cleverly deployed to mask Nazism's true character as a technocratic-industrialist juggernaut. The definitive history of German anti-urbanism and agrarian romanticism argues incisively against this view:

Nothing could be more wrong than to suppose that most of the leading National Socialist ideologues had cynically feigned an agrarian romanticism and hostility to urban culture, without any inner conviction and for merely electoral and propaganda purposes, in order to hoodwink the public ... In reality, the majority of the leading National Socialist ideologists were without any doubt more or less inclined to agrarian romanticism and anti-urbanism and convinced of the need for a relative re-agrarianization. ${ }^{36}$

The question remains, however: To what extent did the Nazis actually implement environmental policies during 
the twelve-year Reich? There is strong evidence that the 'ecological' tendency in the party, though largely ignored today, had considerable success for most of the party's reign. This "green wing" of the NSDAP was represented above all by Walther Darré, Fritz Todt, Alwin Seifert and Rudolf Hess, the four figures who primarily shaped fascist ecology in practice.

\section{Blood and Soil as Official Doctrine}

"The unity of blood and soil must be restored," proclaimed Richard Walther Darré in $1930 .^{37}$ This infamous phrase denoted a quasi-mystical connection between 'blood' (the race or Volk) and 'soil' (the land and the natural environment) specific to Germanic peoples and absent, for example, among Celts and Slavs. For the enthusiasts of Blut und Boden, the Jews especially were a rootless, wandering people, incapable of any true relationship with the land. German blood, in other words, engendered an exclusive claim to the sacred German soil. While the term "blood and soil" had been circulating in völkisch circles since at least the Wilhelmine era, it was Darré who first popularized it as a slogan and then enshrined it as a guiding principle of Nazi thought. Harking back to Arndt and Riehl, he envisioned a thoroughgoing ruralization of Germany and Europe, predicated on a revitalized yeoman peasantry, in order to ensure racial health and ecological sustainability.

Darré was one of the party's chief "race theorists" and was also instrumental in galvanizing peasant support for the Nazis during the critical period of the early 1930s. From 1933 until 1942 he held the posts of Reich Peasant Leader and Minister of Agriculture. This was no minor fiefdom; the agriculture 
ministry had the fourth largest budget of all the myriad Nazi ministries even well into the war. ${ }^{38}$ From this position Darré was able to lend vital support to various ecologically oriented initiatives. He played an essential part in unifying the nebulous proto-environmentalist tendencies in National Socialism:

It was Darré who gave the ill-defined anti-civilization, antiliberal, anti-modern and latent anti-urban sentiments of the Nazi elite a foundation in the agrarian mystique. And it seems as if Darré had an immense influence on the ideology of National Socialism, as if he was able to articulate significantly more clearly than before the value system of an agrarian society contained in Nazi ideology and-above all-to legitimate this agrarian model and give Nazi policy a goal that was clearly oriented toward a far-reaching re-agrarianization. ${ }^{39}$

This goal was not only quite consonant with imperialist expansion in the name of Lebensraum, it was in fact one of its primary justifications, even motivations. In language replete with the biologistic metaphors of organicism, Darré declared: "The concept of Blood and Soil gives us the moral right to take back as much land in the East as is necessary to establish a harmony between the body of our Volk and the geopolitical space." 40

Aside from providing green camouflage for the colonization of Eastern Europe, Darré worked to install environmentally sensitive principles as the very basis of the Third Reich's agricultural policy. Even in its most productivist phases, these precepts remained emblematic of Nazi doctrine. When the "Battle for Production" (a scheme to boost the productivity of the agricultural sector) was proclaimed at 
the second Reich Farmers Congress in 1934, the very first point in the program read "Keep the soil healthy!" But Darre’s most important innovation was the introduction on a large scale of organic farming methods, significantly labeled "lebensgesetzliche Landbauweise," or farming according to the laws of life. The term points up yet again the natural order ideology which underlies so much reactionary ecological thought. The impetus for these unprecedented measures came from Rudolf Steiner's anthroposophy and its techniques of biodynamic cultivation. ${ }^{41}$

The campaign to institutionalize organic farming encompassed tens of thousands of smallholdings and estates across Germany. It met with considerable resistance from other members of the Nazi hierarchy, above all Backe and Göring. But Darré, with the help of Hess and others, was able to sustain the policy until his forced resignation in 1942 (an event which had little to do with his environmentalist leanings). And these efforts in no sense represented merely Darrés personal predilections; as the standard history of German agricultural policy points out, Hitler and Himmler "were in complete sympathy with these ideas." ${ }^{22}$ Still, it was largely Darrés influence in the Nazi apparatus which yielded, in practice, a level of government support for ecologically sound farming methods and land use planning unmatched by any state before or since.

For these reasons Darré has sometimes been regarded as a forerunner of the contemporary Green movement. His biographer, in fact, once referred to him as the "father of the Greens." ${ }^{33}$ Her book Blood and Soil, undoubtedly the best single source on Darré in either German or English, 
consistently downplays the virulently fascist elements in his thinking, portraying him instead as a misguided agrarian radical. This grave error in judgement indicates the powerfully disorienting pull of an 'ecological' aura. Darrés published writings alone, dating back to the early twenties, are enough to indict him as a rabidly racist and jingoist ideologue particularly prone to a vulgar and hateful antisemitism (he spoke of Jews, revealingly, as "weeds"). His decade-long tenure as a loyal servant and, moreover, architect of the Nazi state demonstrates his dedication to Hitler's deranged cause. One account even claims that it was Darré who convinced Hitler and Himmler of the necessity of exterminating the Jews and Slavs. ${ }^{44}$ The ecological aspects of his thought cannot, in sum, be separated from their thoroughly Nazi framework. Far from embodying the 'redeeming' facets of National Socialism, Darré represents the baleful specter of ecofascism in power.

\section{Implementing the Ecofascist Program}

It is frequently pointed out that the agrarian and romantic moments in Nazi ideology and policy were in constant tension with, if not in flat contradiction to, the technocraticindustrialist thrust of the Third Reich's rapid modernization. What is not often remarked is that even these modernizing tendencies had a significant ecological component. The two men principally responsible for sustaining this environmentalist commitment in the midst of intensive industrialization were Reichsminister Fritz Todt and his aide, the high-level planner and engineer Alwin Seifert. 
Todt was "one of the most influential National Socialists," directly responsible for questions of technological and industrial policy. At his death in 1942 he headed three different cabinetlevel ministries in addition to the enormous quasi-official Organisation Todt, and had "gathered the major technical tasks of the Reich into his own hands." ${ }^{36}$ According to his successor, Albert Speer, Todt "loved nature" and "repeatedly had serious run-ins with Bormann, protesting against his despoiling the landscape around Obersalzberg." ${ }^{\prime 47}$ Another source calls him simply "an ecologist." ${ }^{38}$ This reputation is based chiefly on Todt's efforts to make Autobahn construction-one of the largest building enterprises undertaken in this century-as environmentally sensitive as possible.

The pre-eminent historian of German engineering describes this commitment thus: "Todt demanded of the completed work of technology a harmony with nature and with the landscape, thereby fulfilling modern ecological principles of engineering as well as the 'organological' principles of his own era along with their roots in völkisch ideology."49 The ecological aspects of this approach to construction went well beyond an emphasis on harmonious adaptation to the natural surroundings for aesthetic reasons; Todt also established strict criteria for respecting wetlands, forests and ecologically sensitive areas. But just as with Arndt, Riehl and Darré, these environmentalist concerns were inseparably bound to a völkisch-nationalist outlook. Todt himself expressed this connection succinctly: "The fulfillment of mere transportation purposes is not the final aim of German highway construction. The German highway must be an expression of its surrounding landscape and an expression of the German essence."50 
Todt's chief advisor and collaborator on environmental issues was his lieutenant Alwin Seifert, whom Todt reportedly once called a "fanatical ecologist." ${ }^{11}$ Seifert bore the official title of Reich Advocate for the Landscape, but his nickname within the party was "Mr. Mother Earth." The appellation was deserved; Seifert dreamed of a "total conversion from technology to nature," ${ }^{2}$ and would often wax lyrical about the wonders of German nature and the tragedy of "humankind's" carelessness. As early as 1934 he wrote to Hess demanding attention to water issues and invoking "work methods that are more attuned to nature." ${ }^{53}$ In discharging his official duties Seifert stressed the importance of wilderness and energetically opposed monoculture, wetlands drainage and chemicalized agriculture. He criticized Darré as too moderate, and "called for an agricultural revolution towards 'a more peasant-like, natural, simple' method of farming, 'independent of capital." "54

With the Third Reich's technological policy entrusted to figures such as these, even the Nazis' massive industrial build-up took on a distinctively green hue. The prominence of nature in the party's philosophical background helped ensure that more radical initiatives often received a sympathetic hearing in the highest offices of the Nazi state. In the mid-thirties Todt and Seifert vigorously pushed for an all-encompassing Reich Law for the Protection of Mother Earth "in order to stem the steady loss of this irreplaceable basis of all life." ${ }^{55}$ Seifert reports that all of the ministries were prepared to co-operate save one; only the minister of the economy opposed the bill because of its impact on mining. 
But even near-misses such as these would have been unthinkable without the support of Reich Minister Rudolf Hess, who provided the "green wing" of the NSDAP a secure anchor at the very top of the party hierarchy. It would be difficult to overestimate Hess's power and centrality in the complex governmental machinery of the National Socialist regime. He joined the party in 1920 as member \#16, and for two decades was Hitler's devoted personal deputy. He has been described as "Hitler's closest confidant," ${ }^{56}$ and the Führer himself referred to Hess as his "closest advisor." ${ }^{57}$ Hess was not only the highest party leader and second in line (after Göring) to succeed Hitler; in addition, all legislation and every decree had to pass through his office before becoming law.

An inveterate nature lover as well as a devout Steinerite, Hess insisted on a strictly biodynamic diet-not even Hitler's rigorous vegetarian standards were good enough for himand accepted only homeopathic medicines. It was Hess who introduced Darré to Hitler, thus securing the "green wing" its first power base. He was an even more tenacious proponent of organic farming than Darré, and pushed the latter to take more demonstrative steps in support of the lebensgesetzliche Landbauweise..$^{58} \mathrm{His}$ office was also directly responsible for land use planning across the Reich, employing a number of specialists who shared Seifert's ecological approach. ${ }^{59}$

With Hess's enthusiastic backing, the "green wing" was able to achieve its most notable successes. As early as March 1933, a wide array of environmentalist legislation was approved and implemented at national, regional and local levels. These measures, which included reforestation programs, bills protecting animal and plant species, and preservationist 
decrees blocking industrial development, undoubtedly "ranked among the most progressive in the world at that time." ${ }^{60}$ Planning ordinances were designed for the protection of wildlife habitat and at the same time demanded respect for the sacred German forest. The Nazi state also created the first nature preserves in Europe.

Along with Darrés efforts toward re-agrarianization and support for organic agriculture, as well as Todt and Seifert's attempts to institutionalize an environmentally sensitive land use planning and industrial policy, the major accomplishment of the Nazi ecologists was the Reichsnaturschutzgesetz of 1935 . This completely unprecedented "nature protection law" not only established guidelines for safeguarding flora, fauna, and "natural monuments" across the Reich; it also restricted commercial access to remaining tracts of wilderness. In addition, the comprehensive ordinance "required all national, state and local officials to consult with Naturschutz authorities in a timely manner before undertaking any measures that would produce fundamental alterations in the countryside." ${ }^{\prime 1}$

Although the legislation's effectiveness was questionable, traditional German environmentalists were overjoyed at its passage. Walter Schoenichen declared it the "definitive fulfillment of the völkisch-romantic longings," ${ }^{\prime 2}$ and Hans Klose, Schoenichen's successor as head of the Reich Agency for Nature Protection, described Nazi environmental policy as the "high point of nature protection" in Germany. Perhaps the greatest success of these measures was in facilitating the "intellectual realignment of German Naturschutz" and the integration of mainstream environmentalism into the Nazi enterprise. ${ }^{63}$ 
While the achievements of the "green wing" were daunting, they should not be exaggerated. Ecological initiatives were, of course, hardly universally popular within the party. Goebbels, Bormann, and Heydrich, for example, were implacably opposed to them, and considered Darré, Hess and their fellows undependable dreamers, eccentrics, or simply security risks. This latter suspicion seemed to be confirmed by Hess's famed flight to Britain in 1941; after that point, the environmentalist tendency was for the most part suppressed. Todt was killed in a plane crash in February 1942, and shortly thereafter Darré was stripped of all his posts. For the final three years of the Nazi conflagration the "green wing" played no active role. Their work, however, had long since left an indelible stain.

\section{Fascist Ecology in Context}

To make this dismaying and discomforting analysis more palatable, it is tempting to draw precisely the wrong conclusion-namely, that even the most reprehensible political undertakings sometimes produce laudable results. But the real lesson here is just the opposite: Even the most laudable of causes can be perverted and instrumentalized in the service of criminal savagery. The "green wing" of the NSDAP was not a group of innocents, confused and manipulated idealists, or reformers from within; they were conscious promoters and executors of a vile program explicitly dedicated to inhuman racist violence, massive political repression and worldwide military domination. Their 'ecological' involvements, far from offsetting these fundamental commitments, deepened 
and radicalized them. In the end, their configuration of environmental politics was directly and substantially responsible for organized mass murder.

No aspect of the Nazi project can be properly understood without examining its implication in the holocaust. Here, too, ecological arguments played a crucially malevolent role. Not only did the "green wing" refurbish the sanguine antisemitism of traditional reactionary ecology; it catalyzed a whole new outburst of lurid racist fantasies of organic inviolability and political revenge. The confluence of anti-humanist dogma with a fetishization of natural 'purity' provided not merely a rationale but an incentive for the Third Reich's most heinous crimes. Its insidious appeal unleashed murderous energies previously untapped. Finally, the displacement of any social analysis of environmental destruction in favor of mystical ecology served as an integral component in the preparation of the final solution:

To explain the destruction of the countryside and environmental damage, without questioning the German people's bond to nature, could only be done by not analysing environmental damage in a societal context and by refusing to understand them as an expression of conflicting social interests. Had this been done, it would have led to criticism of National Socialism itself since that was not immune to such forces. One solution was to associate such environmental problems with the destructive influence of other races. National Socialism could then be seen to strive for the elimination of other races in order to allow the German people's innate understanding and feeling of nature to assert itself, hence securing a harmonic life close to nature for the future. ${ }^{64}$ 
This is the true legacy of ecofascism in power: "genocide developed into a necessity under the cloak of environment protection." 65

The experience of the "green wing" of German fascism is a sobering reminder of the political volatility of ecology. It certainly does not indicate any inherent or inevitable connection between ecological issues and right-wing politics; alongside the reactionary tradition surveyed here, there has always been an equally vital heritage of left-libertarian ecology, in Germany as elsewhere ${ }^{66}$ But certain patterns can be discerned: "While concerns about problems posed by humankind's increasing mastery over nature have increasingly been shared by ever larger groups of people embracing a plethora of ideologies, the most consistent 'pro-natural order' response found political embodiment on the radical right." ${ }^{67}$ This is the common thread which unites merely conservative or even supposedly apolitical manifestations of environmentalism with the straightforwardly fascist variety.

The historical record does, to be sure, belie the vacuous claim that "those who want to reform society according to nature are neither left nor right but ecologically minded." 68 Environmental themes can be mobilized from the left or from the right, indeed they require an explicit social context if they are to have any political valence whatsoever. "Ecology" alone does not prescribe a politics; it must be interpreted, mediated through some theory of society in order to acquire political meaning. Failure to heed this mediated interrelationship between the social and the ecological is the hallmark of reactionary ecology. 
As noted above, this failure most commonly takes the form of a call to "reform society according to nature," that is, to formulate some version of 'natural order' or 'natural law' and submit human needs and actions to it. As a consequence, the underlying social processes and societal structures which constitute and shape people's relations with their environment are left unexamined. Such willful ignorance, in turn, obscures the ways in which all conceptions of nature are themselves socially produced, and leaves power structures unquestioned while simultaneously providing them with apparently 'naturally ordained' status. Thus the substitution of eco-mysticism for clear-sighted social-ecological inquiry has catastrophic political repercussions, as the complexity of the society-nature dialectic is collapsed into a purified Oneness. An ideologically charged 'natural order' does not leave room for compromise; its claims are absolute.

For all of these reasons, the slogan advanced by many contemporary Greens, "We are neither right nor left but up front," is historically naive and politically fatal. The necessary project of creating an emancipatory ecological politics demands an acute awareness and understanding of the legacy of classical ecofascism and its conceptual continuities with present-day environmental discourse. An 'ecological' orientation alone, outside of a critical social framework, is dangerously unstable. The record of fascist ecology shows that under the right conditions such an orientation can quickly lead to barbarism. 